\title{
Agricultural Frontiers, Health Care, and Population Size Impact the Recovery Patterns of Brazilian Indigenous Nations
}

\author{
Felipe Augusto Maurin Krsulovic ${ }^{1}$ (D) $\cdot$ Fernanda Araujo Casares $^{2} \cdot$ Mauricio Lima $^{1}$
}

Published online: 7 May 2019

(C) The Author(s) 2019

\begin{abstract}
After centuries of decline, the populations of indigenous nations in Brazil began to increase in the 1970s. Population Ecology theory predicts that population size affects the dynamics of three basic recovery patterns: intra-specific cooperation (a positive effect of population size); competition (a negative effect); and exponential growth (no effect of population size). We analyzed the dynamics and recent history of 25 Brazilian indigenous populations using a cross-sectional approach to understand how exogenous and cultural variables (e.g., deforestation, diet richness) interact with population levels. We found that population size, access to health care, the extent of indigenous territories, and degree of deforestation impact the recovery of indigenous population levels.
\end{abstract}

Keywords Deforestation $\cdot$ Health care $\cdot$ Intra-population processes $\cdot$ Indigenous populations $\cdot$ Local environmental knowledge $\cdot$ Land rights $\cdot$ Brazil

\section{Introduction}

American indigenous populations suffered drastic declines and widespread acculturation following the arrival and expanding settlement of Europeans from the late fifteenth century onward (Ribeiro 1956). Conservative estimates of indigenous pre-contact Brazilian populations report around three million people with 1000 distinct languages (Melatti 1993). After 500 years of contact, the indigenous populations are now estimated at only slightly more than 800,000 individuals with approximately 180 languages persisting (IBGE 2010; S1 Text).

In the last century, Latin America experienced a political shift towards the protection of indigenous rights (McSweeney and Shahna 2005) notably in Brazil during the 1950s and 1960 s, peaking with the creation of the Parque Indígena do

Electronic supplementary material The online version of this article (https://doi.org/10.1007/s10745-019-0069-4) contains supplementary material, which is available to authorized users.

Felipe Augusto Maurin Krsulovic augustomaurin@gmail.com

1 Pontificia Universidad Católica de Chile, Santiago, Chile

2 Instituto Brasileiro de Biodiversidade, Rio de Janeiro, RJ 20031-205, Brazil
Xingu (PIX) in 1961. After 22 years of dictatorship, the Brazilian Constitution of 1988 explicitly guaranteed the rights of indigenous nations to a territory and access to basic health care. Since then, Indigenous Territories (ITs) have expanded further and currently occupy 13\% of the country (Instituto Socioambiental 2011). Indigenous communities began to receive better health assistance and government subsidies that reduced mortality rates and allowed demographic recovery rates with an average of approximately $3 \%$ per year (estimated from at least 50 indigenous nations), a value much higher than the national rates (Melatti 1993; Ricardo 2000; Pagliaro et al. 2005; Instituto Socioambiental 2011; IBGE 2014). This growth has led to many nations regaining pre-contact population levels, allowing them to maintain their social and cultural integrity (Pozzobon 1994; S2-S4 Text).

Nonetheless, Brazilian indigenous nations continue to endure higher disease burdens and mortality levels as well as lower life expectancies than non-indigenous populations (Junior 1985, 1989; Junior and Santos 1991; Fagundes et al. 2004; Orellana et al. 2006). ITs are subject to habitat destruction (Fig. 1) and land conflicts arising from illegal mining and logging activities and expansion of agricultural frontiers, particularly for ranching and large-scale cultivation enterprises ${ }^{1}$ (Villas

\footnotetext{
${ }^{1}$ Agriculture and husbandry currently represent more than $23 \%$ of Brazilian annual GDP.
} 
Bôas and Villas Bôas 1994; Flowers 1994; Junior et al. 2002; Baruzzi 2005; Fearnside 2005; Paula 2005; Barbosa et al. 2008; Filho and de Souza 2009; Lemos and Silva 2011). These developments serve to undermine any benefits to indigenous communities brought by government designation of their territories and improved access to health care (Ribeiro 1970; S5 and S6 Text; Fig. 1).

Many studies have addressed the role of life-history traits, e.g. family size, age of first son, age of marriage, among others traits important to fitness (Hotz and Miller 1988; Pennington and Harpending 1988; Kaplan 1996; Hill and Kaplan 1999; Ricardo 2000; Pagliaro 2002; Maia et al. 2004; Pagliaro and Junqueira 2007; Machado et al. 2009; Pagliaro et al. 2009), diseases (Ribeiro 1956, 1970; Orellana et al. 2006; Instituto Socioambiental 2011), climate (Lima 2014; Lima et al. 2016), habitat degradation (Garfield 2001; Filho and de Souza. 2009; Instituto Socioambiental 2011), diet and foraging strategies (Belovsky 1988; Balée 1992; Smith and Winterhalder, 2003) to human populations and specifically to hunter-gatherer and horticultural societies (Early and Peters 1990; Hill and Hurtado 1996; Walker et al. 2006; Hamilton et al. 2009). Yet, only a few have simultaneously addressed the potential impacts of the interaction of population size and exogenous variables on population dynamics (Hamilton et al. 2009; Lima and Berryman 2011; Lima 2014; Lima et al. 2016).

Population Ecology theory adopts principles from Dynamic Systems theory, which identifies both endogenous and exogenous processes that could affect the dynamics of any variable (Royama 1992; Berryman 1999; Turchin 2001; Hopfenberg 2003). Endogenous processes occur when a variable affects directly or indirectly (through another variable) its own rate of change and dynamics, as in the predator-prey interaction. An exogenous process occurs when a variable affects another, but the effect does not feed back, e.g., climate variables, natural disasters, the introduction of invasive species, and wars could affect population dynamics (Lima and Berryman 2011; Lima 2014; Lima et al. 2016).

Population Ecology Theory dictates that under a favorable and constant environment any population may grow exponentially (Ginzburg 1986; Royama 1992; Berryman 1999). In this case, the recovery rate is constant and independent of population size. There are two basic deviations from exponential growth: (1) when population size enhances environmental suitability such as through cooperative activities (intraspecific cooperation) in a stressful environment (Allee, 1932; Berryman 1999; Luděk et al. 2006); and (2) when population size has a negative effect on environmental suitability
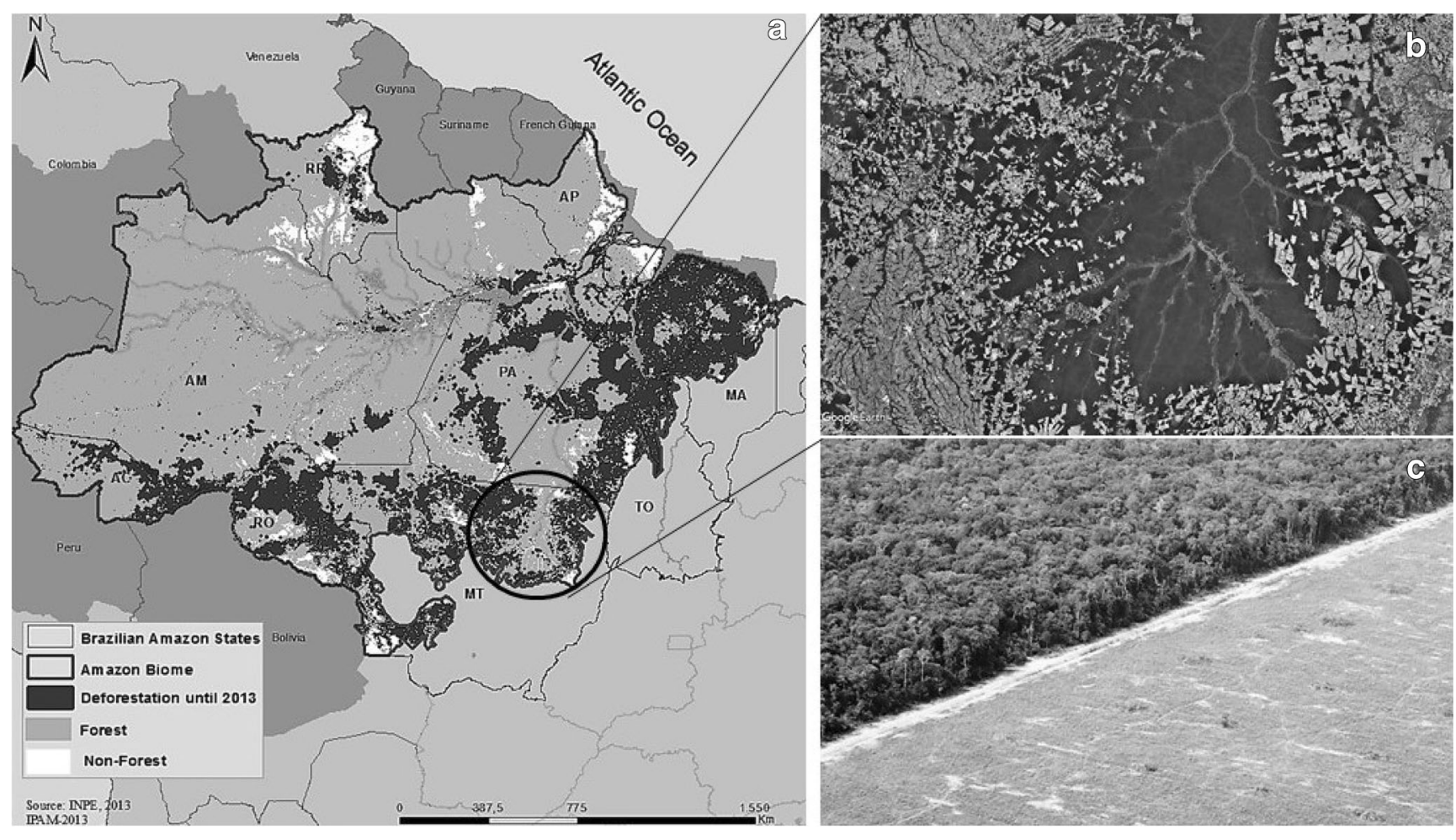

Fig. 1 a Deforested areas (dark grey) in Amazonia Legal (AL) until 2013. $\mathrm{AL}$ is a macro socio-economic and environmental region. It comprises the dense-ombrophilous biome in northern Brazil and consists in a transitional region (Central-west) to other biomes like savanna (Cerrado), semidecidous, among others. The agricultural frontiers have been advancing from central-west to northern region in the last decades, following the
Brazilian official roads (Brando et al. 2013). (B) The Parque Indígena do Xingu (PIX, in dark grey) surrounded by deforested areas (light grey, source: Google Earth, obtained in January 14, 2018). (C) Photograph showing the PIX frontier with agriculture area obtained from Instituto Socioambiental, 2011) 
(intra-specific competition) such as by reducing per capita available resources (Malthus 1798; Verhulst 1838; Allee, 1932; Royama 1992; Berryman 1999; Turchin 2001; Hopfenberg 2003; Luděk et al. 2006). In summary, adding individuals to a population may either enhance or deplete environmental suitability (Malthus 1798; Verhulst 1838; Royama 1992; Berryman 1999; Turchin 2001; Hopfenberg 2003). Moreover, endogenous and exogenous variables can interact, influencing the dynamics of human populations (Lima and Berryman 2011; Lima 2014; Lima et al. 2016).

These ecological principles and models have been used to explore and explain the human dynamics of pre- and postindustrial periods ranging from small non-hierarchical societies to large empires (Royama 1992; Berryman 1999; Turchin 2001; Lima and Berryman 2011). By taking into account the effects of limiting factors and potential feedback loops (see below), here we aim to correlate recent historical events with the demography of 25 Brazilian indigenous nations and to explore the interaction between exogenous variables and population sizes to explain their observed population growth rates from the perspective of Population Ecology Theory (Royama 1992; Berryman 1999; Turchin 2001; Lima and Berryman 2011).

\section{Methods}

We analyzed the dynamics of 25 Brazilian indigenous nations (Table S1). We selected nations with at least five population size records within the period 1930 to 2010/12. We focused on the relationship among the population per capita rate of change (R), population size, and external variables. $\mathrm{R}$ can be estimated as the natural logarithmic ratio between consecutive population sizes or as the natural logarithmic difference between natality and mortality rates in a closed population (Royama 1992; Berryman 1999).

Using principles from System Dynamics Theory and biological interactions, population ecologists have developed a framework to explore the contributions of distinct drivers to population dynamics. R measures the average (i.e., per capita) fitness of the population, i.e., how the average individual performs in the population. Hence, $\mathrm{R}$ can be used as a proxy of per capita life-standard. Under a favorable environment and with sufficient resources individuals have more children and survive for longer periods ( $\mathrm{R}$ is positive) than under unfavorable environmental conditions ( $\mathrm{R}$ is negative) (Royama 1992; Berryman 1999).

The endogenous view holds that as the population grows individuals may become more efficient in food acquisition, finding sexual partners (i.e., changes in sex ratio), as well as in protecting themselves against predators (Allee, 1932; Berryman 1999; Luděk et al. 2006; Gregory et al. 2010). Population growth may allow for better labor organization
(Boserup 1965, 1981), reducing the costs and increasing the benefits of economic and social activities that are important to the social and cultural persistence of any indigenous population. Population growth improves individuals' life-standards, and thus accelerates its own rate of increase (R). It marks a positive feedback process biologically known as intra-specific cooperation (Berryman 1999) (S1 Fig. and S7 Text).

However, demographic cooperation is unstable; it cannot persist indefinitely. The positive demographic effects of accumulated cooperative activities eventually reach a maximum for a given environment. Life-quality decelerates and enters a new phase where population growth is independent of population size. These populations exhibit an exponential growth pattern, which is also unstable since a population cannot grow indefinitely (Royama 1992; Berryman and Turchin 2001; Ginzburg 1986; Turchin 2001; S1 Fig.).

Nevertheless, as the population increases, individuals may face per capita reductions in resource supply (e.g., space or food), initiating a decline in the population per capita rate of change (R). This process is known as intra-specific competition, and these populations display a logistic growth pattern (Ginzburg 1986; Berryman 1999; Berryman and Turchin 2001; Lima and Berryman 2011; S1 Fig. and S7 Text).

An exogenous process occurs when a variable affects another without, however, being affected by the changes it causes (Royama 1992; Berryman and Turchin 2001), e.g., climate variables, political changes, habitat destruction, the introduction of diseases and vaccines (Lima 2009; Lima and Berryman 2011).

We can summarize a general R-function for any population (Royama 1992; Berryman 1999):

$R-$ function $\sim\left(N_{t-d}\right.$, Exogenous variables $)$

$\mathrm{R}$ is an undefined function of endogenous $\left(N_{t-d}\right.$ where $\mathrm{t}-\mathrm{d}$ is the time lag) and exogenous processes.

\section{Endogenous Processes $\left(N_{t-d}\right)$}

We aimed to identify nations with similar $\mathrm{R}$ behavior with population size (intra-specific cooperation, competition, and exponential growth). Due to the low number of observations per nation, we first visually explored the relationship between $\mathrm{R}$ and population size for the 25 nations. Depending on whether $\mathrm{R}$ declined, increased, or stayed relatively constant with population size, we classified the nations as intra-specific competition, cooperation, and exponential growth patterns, respectively. To support our classification, we first analyzed Mucaji Yanomami time series, which covers 60 years of annual data. Then, we grouped nations that exhibited the same behavior and fitted the following discrete models (Verhulst 
1838; Gregory et al. 2010) that capture the intra-population principles:

$$
\begin{aligned}
& R=R \max \left(1-\left(N_{t-1} / K\right)\right)^{Q} \\
& R=R \max \left(\left(N_{t-1} / E\right)-1\right)^{T} \\
& R=R \max \left(\left(N_{t-1} / E\right)-1\right)\left(1-\left(N_{T-1} / K\right)\right)
\end{aligned}
$$

Eq. 2, Eq. 3 and Eq. 4 capture, respectively, the intraspecific competition, cooperation, and both behaviors. $R$ is the population per capita rate of change, $R_{\max }$ represents the maximum per capita rate of change, $N_{t-1}$ is the population size at a previous observation, $K$ is the carrying capacity, i.e., the stable population size determined by the supply of resources in the environment and the caloric demands of the individuals to survive and reproduce. Above $K$, individuals suffer from food scarcity and mortality is higher than natality, resulting in population decline. Below $K$, there is sufficient resource surplus and population grows. $Q$ is a non-linear term that reflects the intensity of intra-specific competition around $K$. $E$ denotes an unstable equilibrium population size, where, if higher, population always grows and, if lower, it tends towards extinction; $T$ represents how fast a population deviates from the unstable equilibrium size (Berryman 1999).

We also explored the patterns of natality, mortality, and migrations rates in order to identify which contributed to the observed R behavior for the Kawaiweté, Ikpeng, Kamaiurá, and Kisêdjê, the nations for which there is available data. We used the Partial Least Squared Regression (PLSR), with R levels as the response variable and the demographic components and population size as exploratory variables. PLSR is an extension of multiple regression analyses and is useful when the number of exploratory variables is higher than or similar to the number of observations. PLSR groups non-independent exploratory variables on orthogonal linear gradients maximizing the covariance between scores and loadings of exploratory and response variables (Naes and Martens 1985; Bates and Watts, 1988; Tobias 2003; Carrascal et al. 2009).

The behavior of $\mathrm{R}$ in function of population size will suggest the actions of the cooperation or competition (or the lack of it), and the PLSR analysis (Kawaiweté, Ikpeng, Kamaiurá, and Kisêdjê) will suggest the demographic paths of the effects of endogenous and exogenous processes.

\section{Exogenous Variables}

Endogenous processes may interact with external variables to affect the dynamics of a population (Berryman 1999). Theory posits that external variables are determinant if they also affect the demographic components (natality, mortality, and migration) of the population per capita rate of change (Berryman 1999). Thus we reviewed the recent history of the 25 nations from the literature and websites (<http://pib.Socioambiental .org/pt>ref) looking for variables and processes that could affect R's demographic components. We performed a multivariate crosssectional analysis to explore the effects of potential exogenous variables on the dynamics. Based on our review and available data, we can rewrite the R-function as follows:

$R \sim f\left(N_{t-d}\right.$, Threats, Number of villages, Diet items, Number of ITs,

Total territory size, Numbers of governmental and ONG projects, Number of biomes)

Here, $N_{t-d}$ refers to initial population size during recovery period, which was used as a proxy of the contribution of population size to the dynamics. The threats can be divided into extractive (e.g., illegal logging, mining) and land pressures (e.g., illegal invasions and settlements) and may be acting as negative exogenous variables (S2, S3 and S4 Text and Fig. 1). The creation of new villages may represent a cost to individuals (e.g., land clearing, construction of houses, migration) but may also ease potential problems of population growth (e.g., local resource depletion) by distributing individuals throughout the territory (S1 Table). Diet items are the variety of hunted, gathered, and cultivated species used for subsistence. The number of biomes found inside the ITs (e.g., semi-arid, dense-ombrophilous, semi-decidualombrophilous, among others) (Instituto Socioambiental 2011) was used as a proxy of ecosystem diversity invoking the diversity-equilibrium theory (Odum 1953; MacArthur 1955; Elton, 1958; Chu and Tai 2001). Briefly, the theory postulates that food-webs with more species are more resistant and resilient than less diverse systems when faced by external perturbations. We could posit that indigenous populations living in contact with more biomes would be more resistant and resilient when faced by habitat loss, for example through deforestation. We used the number of governmental and nongovernmental (NGO) projects as a proxy of political awareness about the indigenous rights.

Combining the data set (Eq.5) generated in our review and the data available in the ISA website, we built a Pearson's correlation matrix to investigate the relationship among exogenous variables. We also used the PLSR with a cross-sectional approach to reduce data complexity and ascertain which variables might be more important to explain the $\mathrm{R}$ trend. We used the average rate of change of $\mathrm{R}(\mathrm{dR})$, which captures the general $\mathrm{R}$ trend as the response variable and the data cited above as the exploratory variables (S1 Fig.). We started with the entire set of variables, and step-by-step removed exploratory variables with no or small weights on the PLSR components. We present only the final PLSR results. As noted, multivariate analyses like PLSR are usually used to reduce the complex universe of measured variables. PLSR is an 

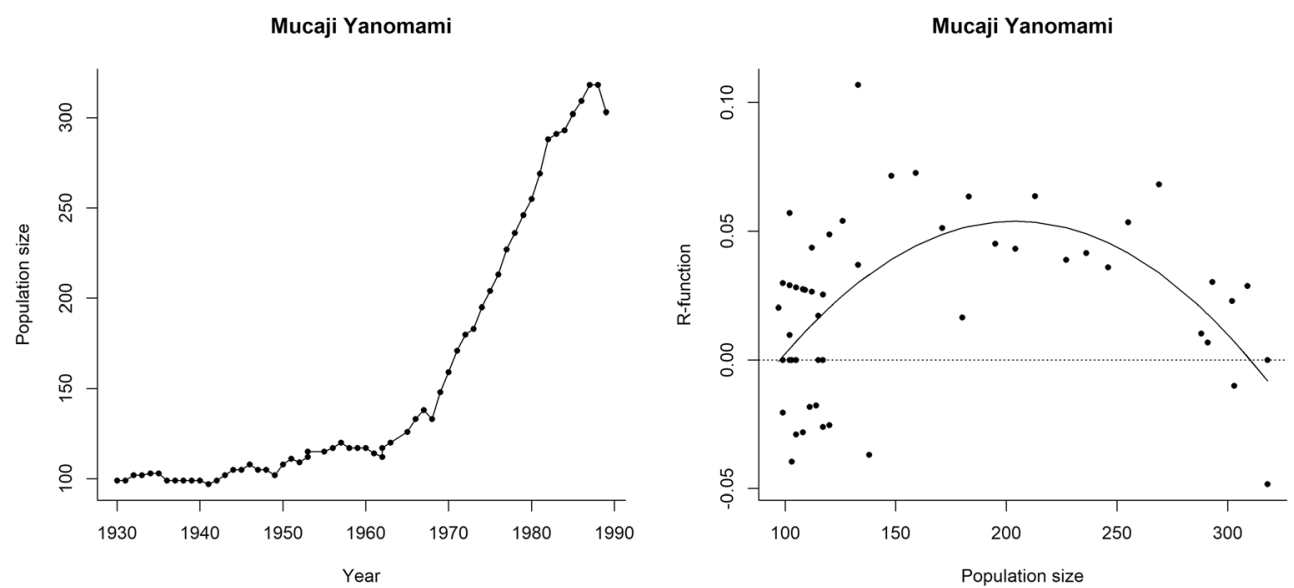

Fig. 2 Mucaji Yanomami time series and the R function. Depicted an initial Allee phase and at the end an intra-specific competition phase. The R function graphic is from 1930 to 1989, when health care improved and time series changed to an accelerating R trend (not shown)

exploratory analysis, not a process of hypothesis testing. Hence the results from the multivariate cross-sectional analysis should be considered as hypotheses. All statistical analyses were performed in the R environment (R Core Team 2016). We fitted Eqs. 3-4 using the nls library in R through nonlinear regression analysis (Mevik and Wehrens 2007). We interpret the statistical results under the scope of Population Ecology Theory and the recent history of indigenous nations (S1 Table and S3 Text).

\section{Results}

\section{Endogenous Processes $\left(\mathbf{N}_{\mathrm{t}-\mathrm{d}}\right)$}

We observed a variety of recovery patterns. Some nations showed a general competition or cooperation recovery, while others presented an exponential growth. We found nations with evidence of an initial cooperation growth and, at higher population size, competition growth. Three nations presented a distinct sequence of behaviors. Gavião Pkopje, Karitiana, and Krikati showed an initial competition phase and a later cooperation growth (Figs. 2, 3, 4, 5 , 6,7 , and 8).

The dynamics of the Mucaji Yanomami is the best time series that we have and reflect most of the behaviors observed in the others nations, describing an initial cooperation phase, followed by periods of exponential and competition growth (Fig. 2). The cooperation-competition model (Eq. 3) explained nearly 50\% of the observed data from 1930 to 1989 . When we increased the time intervals between observations, reducing the noise, the $\mathrm{R}^{2}$ (i.e., the coefficient of determination) of the model increased (Table 1).

We classified nations based on $\mathrm{R}$ behavior in function of population size. We then pooled all demographic data per group. Nations grouped as cooperation, competition, and exponential growth respectively showed a general positive, negative, and independent $\mathrm{R}$ trend with population size (Figs. 2, 3, 4, 5, 6, 7, 8 and Table 1). Regardless of the behavior displayed, we found that $\mathrm{R}$ was related to more changes in natality than mortality levels (Table 2 and Fig. 7). In all cases, mortality was at lower levels and generally declined gradually (Fig. 7).

\section{Exogenous Variables}

The correlation matrix revealed some potential collinearities. Most of the variables were positively correlated to the numbers of indigenous territories and vegetation types (Table 3). The
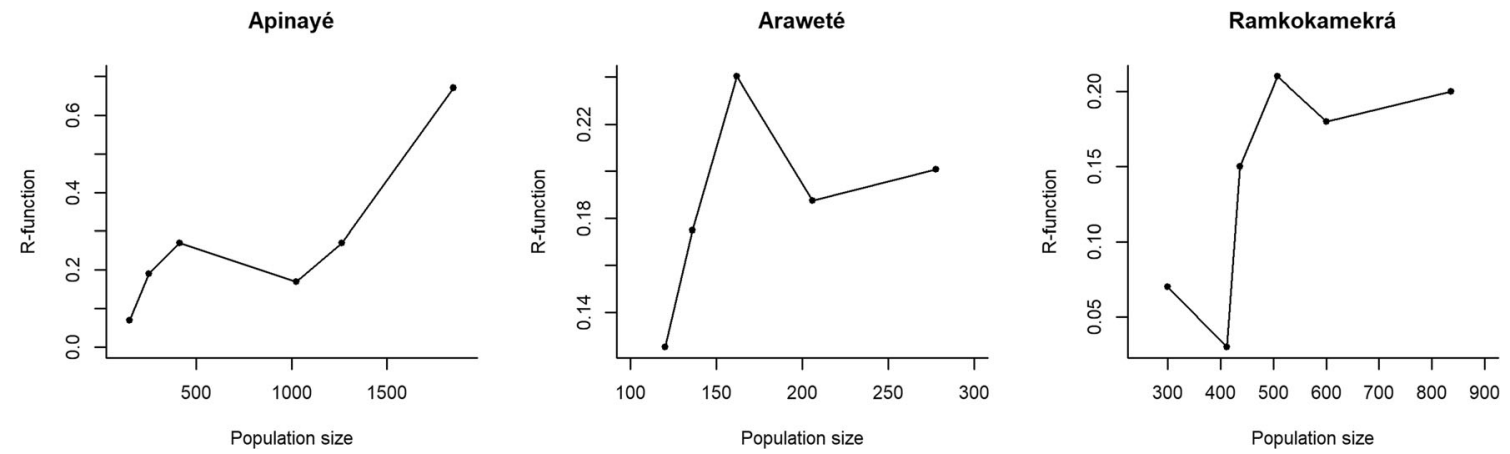

Fig. 3 Time series of indigenous nations and $\mathrm{R}$ functions with accelerating $\mathrm{R}$ behavior 
Hixkaryana

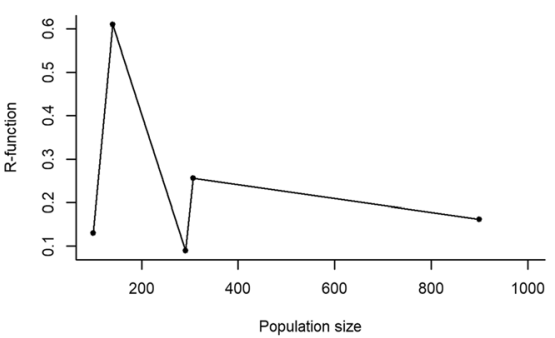

Iny

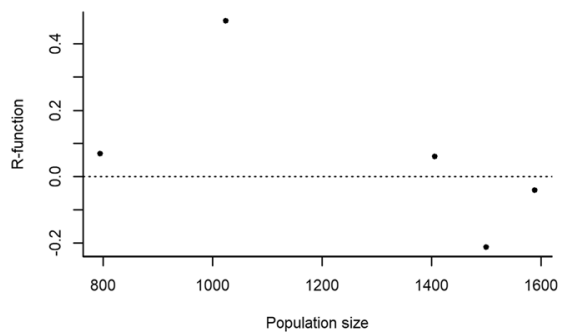

Marubo

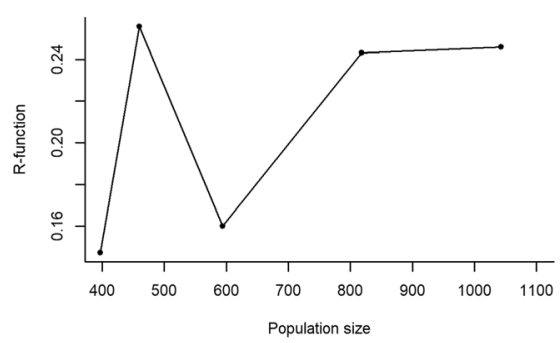

Palikur

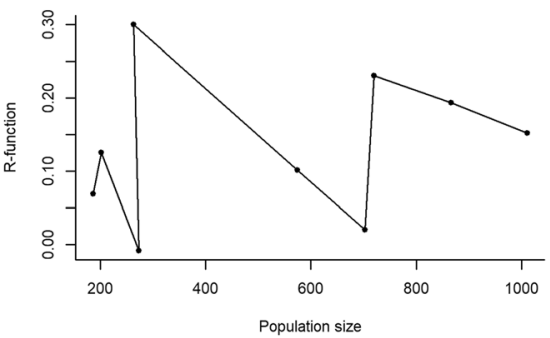

Fig. 4 R-functions of the indigenous nations with visual exponential growth

number of indigenous territories, villages, initial population sizes, illegal extractive pressures, and vegetation richness are probably correlated. Vegetation type negatively correlated with hunted items. Sources of diet are correlated and agriculture is correlated with the numbers of governmental and NGOs projects. Both sources of threats were negatively correlated with hunting, gathering, and agricultural items (Table 4).
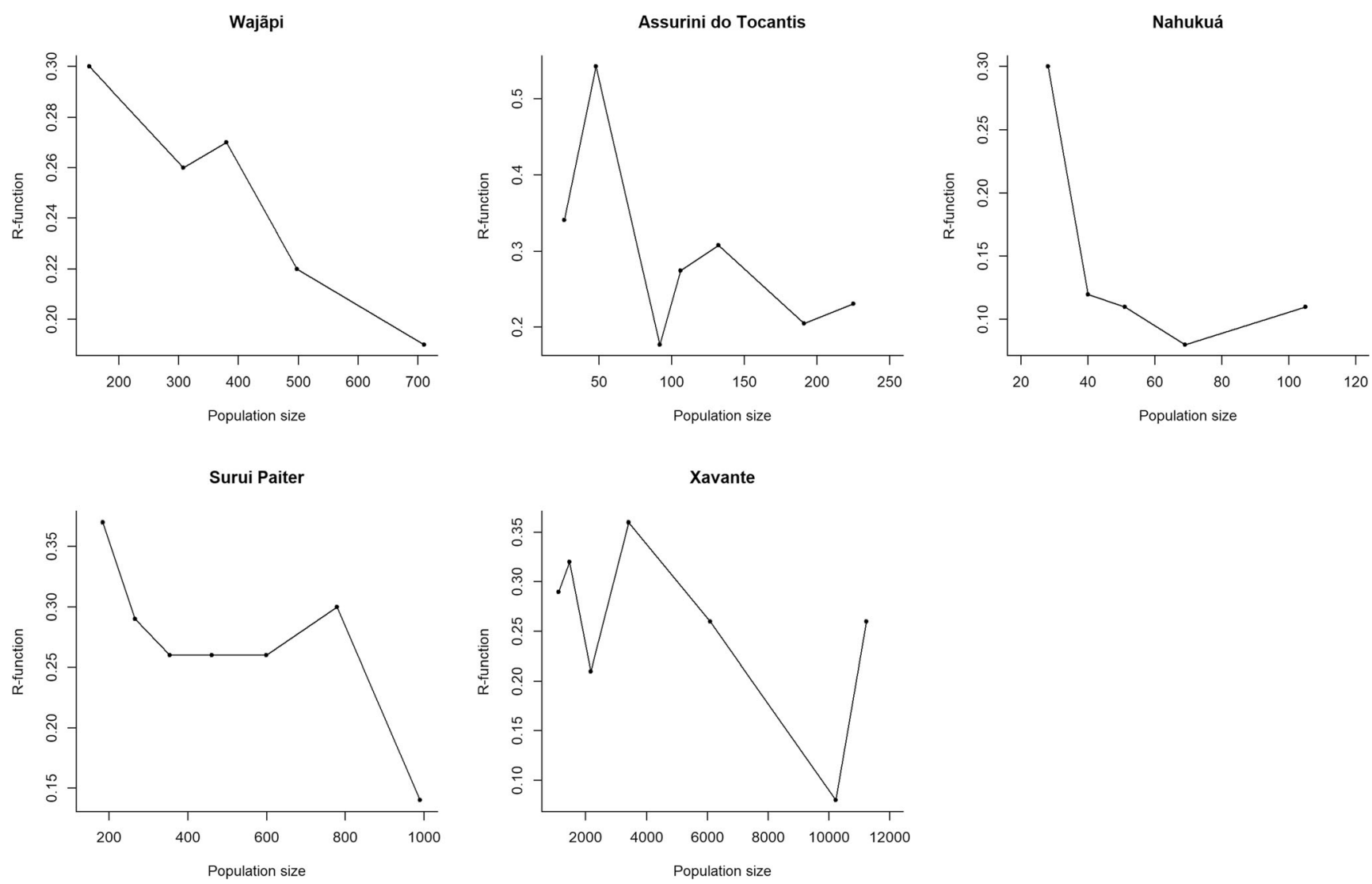

Fig. 5 Time series of indigenous nations and $\mathrm{R}$ functions with overall $\mathrm{R}$ declining behavior 
Wajãpi

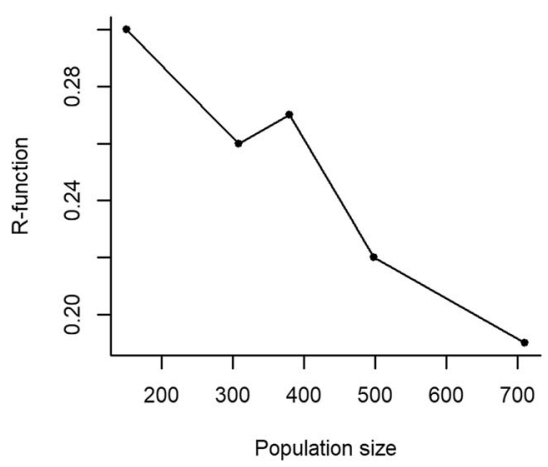

Surui Paiter

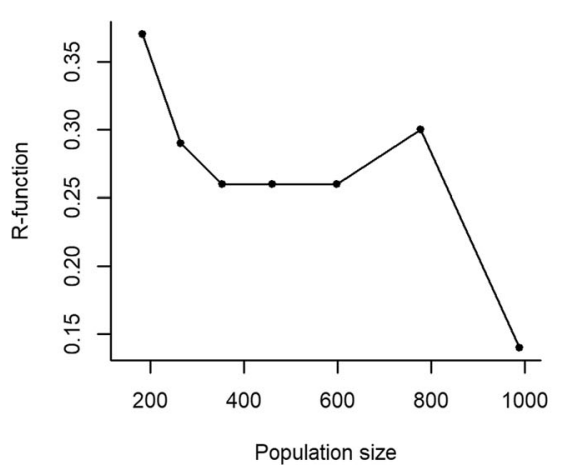

Assurini do Tocantis

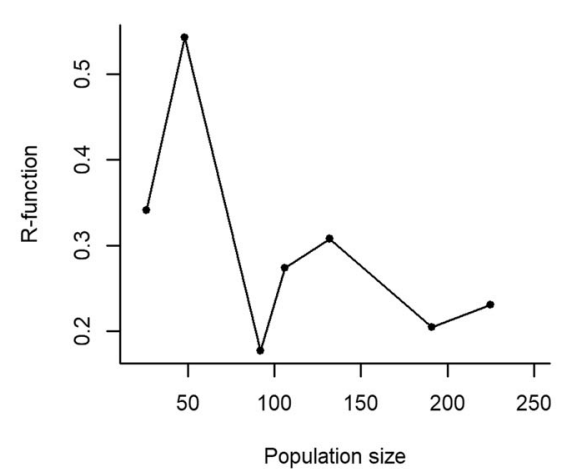

Xavante

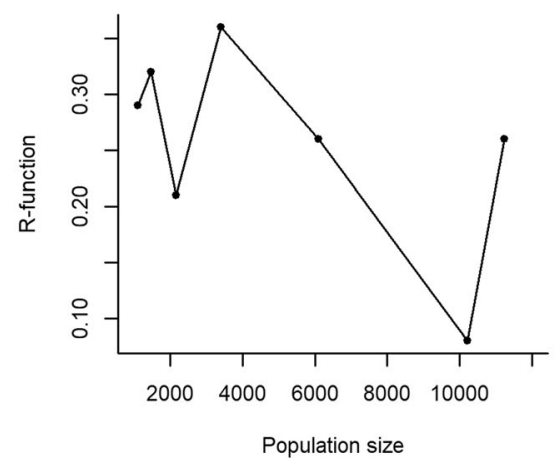

Nahukuá

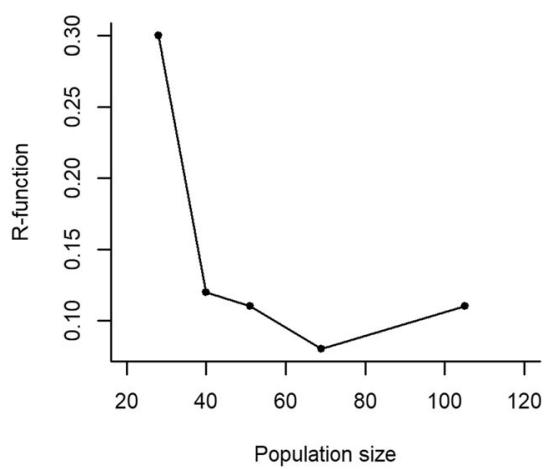

Fig. 6 The R functions of the nations with both accelerating and declining R behaviors. The initial decline trend of the Krikati, Karitiana and Gavião Pykopjê can be related to the costs prior the land homologation

After removing variables with no or small weights on the first PLS component, we retained a small set of variables that could affect $\mathrm{R}$ trends. The first PLS component explained approximately $44 \%$ of the variance observed in $\mathrm{dR}$, while the second component explained $25 \%$. Initial population size and vegetation types weighed heaviest in the first component whereas gathered items showed the highest weight in the second PLS component (Table 4).

\section{Discussion}

Based on our data from the recent history of 25 Brazilian indigenous nations we propose a hypothesis concerning the interaction between the effects of population size and exogenous variables from the perspective of Population Ecology Theory. The population recovery patterns of the Brazilian indigenous nations suggest the existence of intra-specific cooperation and competition processes (or exponential growth) and exogenous variables. The designation of ITs and improved access to health care have reduced mortality levels, leading to natality-driven population per capita rate of change. At the same time, the expansion of agricultural frontiers has been degrading environmental suitability for population growth
(Ribeiro 1970; Villas Bôas and Villas Bôas 1994; Instituto Socioambiental 2011; S3 Text).

Together with health care, officially designated ITs are central to the social and cultural persistence of indigenous populations. The correlation matrix showed that the number of ITs correlates with most other variables. Increasing the number of ITs per nation raises the possibility of confronting new threats and new biomes (positive correlations), and allows higher initial population sizes and the potential for the creation of more villages.

The PLSR results point to the importance of deforestation, population size, and diet to nations' demography. We focus on the results from the first component of the analysis and suggest that the number of biomes may be a proxy for deforestation. Most nations analyzed in this study are from the Central-Western region, which is a transitional area between the dense-ombrophilous forest (Amazon) and other biomes (Brando et al. 2013), presents the highest diversity of the biomes. While this high richness of biomes could invoke the diversity-equilibrium theory (Odum 1953; MacArthur 1955; Elton, 1958; Chu and Tai 2001), in our case of Brazilian indigenous nations the predictions of the diversity-equilibrium theory did not 
Fig. 7 Indigenous nations' available natality and mortality rates. Shows that independent of the behavior, $\mathrm{R}$ is closer related to natality than mortality rates. All nations are from PIX lkpeng

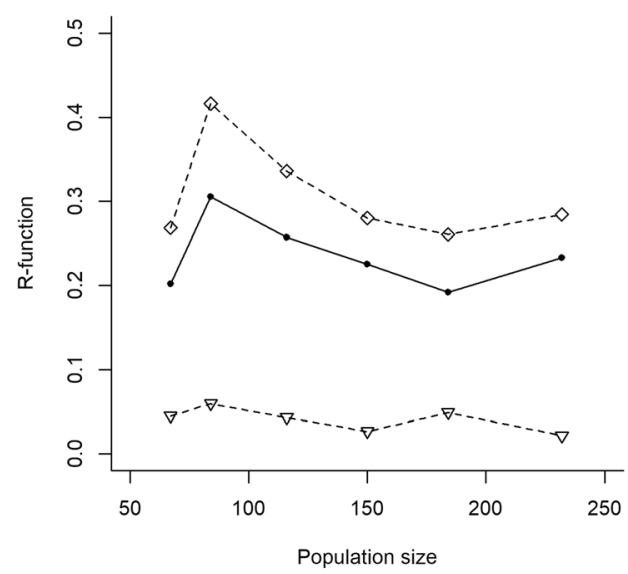

Kamaiurá

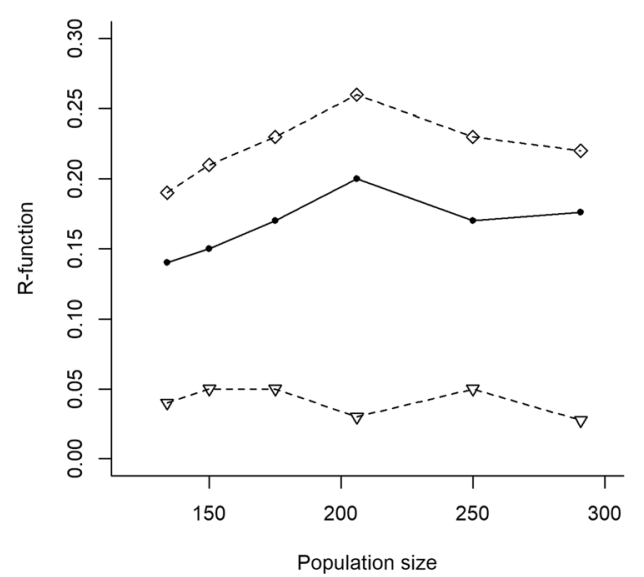

Kawaiwete

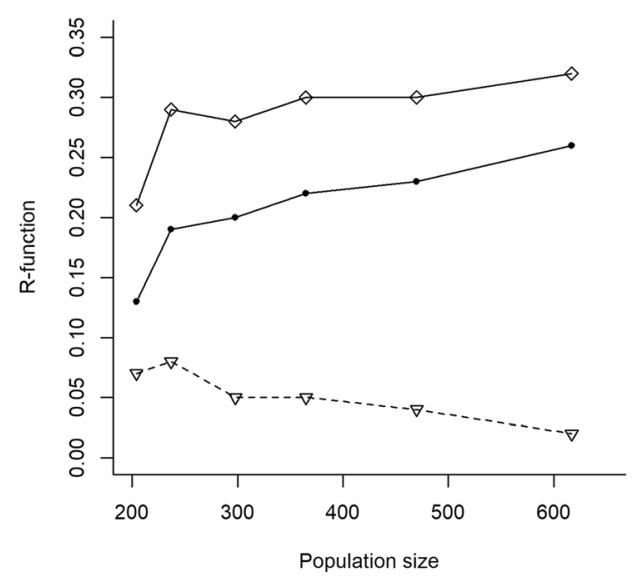

Kisêdjê

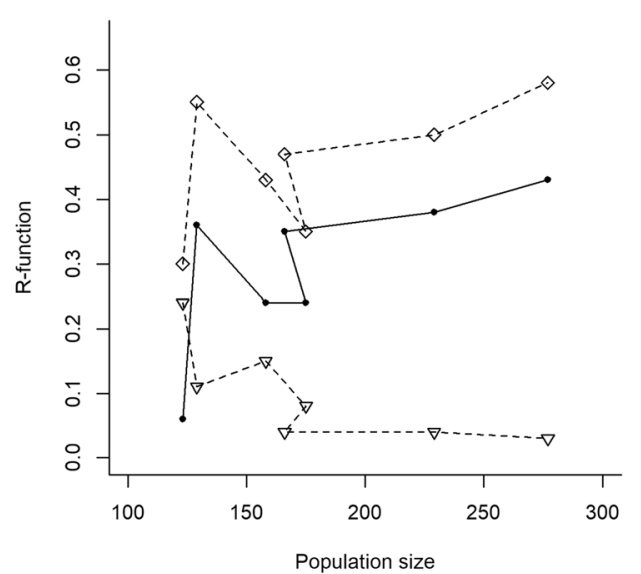

apply (see Methods). First, the dense-ombrophilous forest (the Amazon in the Northern region) present more species than all the other biomes together (Brando et al. 2013). Secondly, the Central-Western region has been suffering from the advance of deforestation for a longer period than the Northern region (Fearnside 2005; Paula 2005; Salomão et al. 2007; Barbosa et al. 2008; Brando et al. 2013). The region with more vegetation types is also where agricultural frontiers have been expanding during the last decades. Therefore, we suggest that vegetation types and habitat degradation correlate geographically and may be a proxy of habitat impoverishment. Hence, the PLSR first component can be interpreted as a combination of deforestation and population size effects on $\mathrm{dR}$.

The Mucaji Yanomami dynamics provide the best evidence of population size effects from our sample of nations. They live in the Northern region (on the frontier with Venezuela) and are therefore more distant from the negative exogenous variables than the other nations we analyzed, located in the Central-Western region. Hence, we can interpret the Mucaji time series as being driven mainly by the effects of population size on the population per capita rate of change $(\mathrm{R})$. Their population started to recover prior to the introduction of health care however, and the initial cooperation recovery phase can be related to sex ratio stabilization and changes in their reproductive regime as they moved from polyandry to monogamy, which is a demographic Allee process with cultural changes (Early and Peters, 1990; Albert 1999).

Habitat degradation could interact with population to explain the dynamics of nations from Central-Western and Northeastern regions. Deforestation reduces availability of big game, fish stocks, and both timber and a range of non-timber forest products (NTFPs) (Ribeiro 1970; Villas Bôas and Villas Bôas 1994; Instituto Socioambiental 2011). We propose that as the advance of agricultural frontiers degrades environmental sustainability, it may increase the importance of cooperative activities, which in turn impact demography (Lima and Berryman 2011; S5 Text). For example, in the PIX, almost all nations with more villages near the agricultural frontiers showed a general $\mathrm{R}$ positive trend (Fig. 9). 


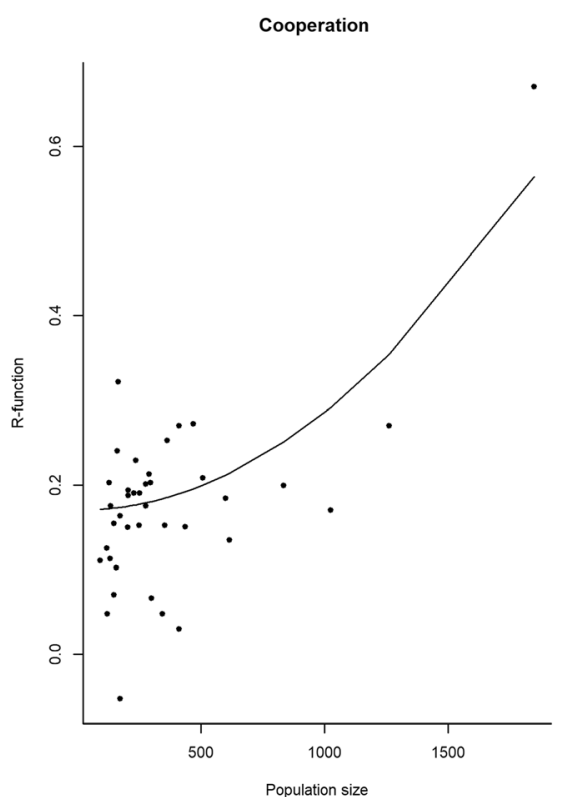

Fig. 8 The R-functions for all data per demographic behavior. Nations were visually grouped by the relationship between $\mathrm{R}$ and population size. Intra-specific cooperation behavior: $\mathrm{R}=0.17+1.155 \mathrm{e}-07 *$ (population size $)^{2}, R^{2}=0.717, F_{1,37}=27.78, p$ value $=1.11 \mathrm{e}-5$. Exponential behavior:
Exponential

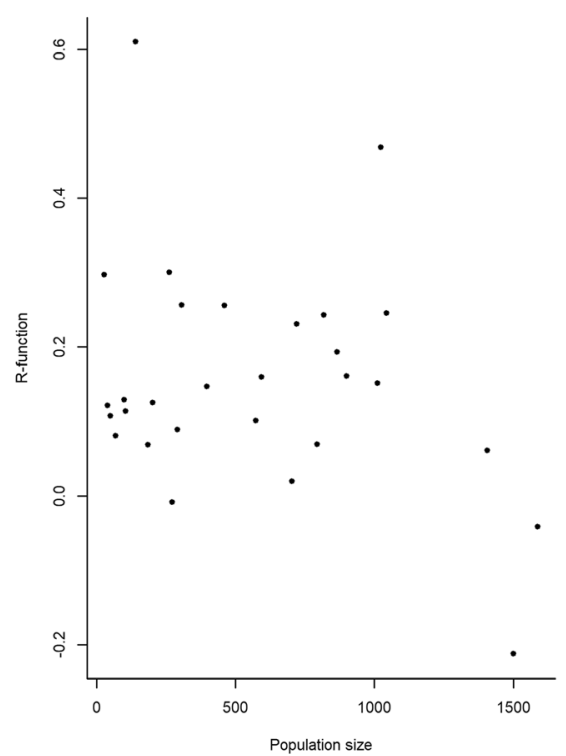

Competition

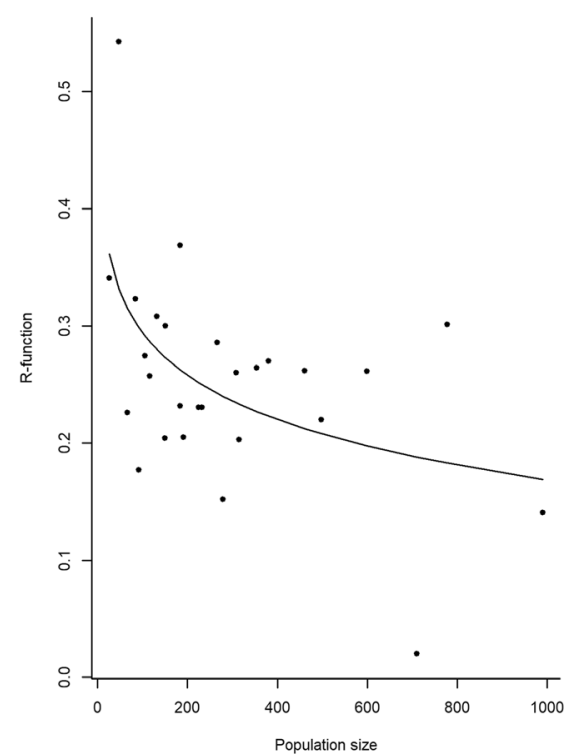

$\mathrm{R}=0.2101-9.393 \mathrm{e}-05^{*}$ (population size), $\mathrm{R}^{2}=0,0460, \mathrm{~F}_{1,27=} 27.78, p$ value $=0.1355$. Intra-specific competition: $\mathrm{R}=1.35 *(1-$ (population size/1524)0.0489), $\mathrm{R}^{2}=0,516, \mathrm{~F}_{1,25=} 6.412, p$ value $=0.0179$

During the $\mathrm{R}$ acceleration phase, population growth together with cooperative activities may improve environments previously degraded by deforestation (S8 and S9 Text). Population growth may diminish individual costs of foraging (hunting and gathering), crop cultivation, house construction, and caring for children (Ribeiro 1970; Berryman 1999; Smith and Winterhalder, 2003; Hamilton et al. 2009).

However, this allows for the potential existence of a minimum population size (E) below which the population becomes susceptible to extinction (Berryman 1999). Indigenous nations have two $\mathrm{E}$, one biological and other cultural (Pozzobon 1994). Any human population needs a minimal population size to function culturally as a group. Some activities both social and related to subsistence (e.g., group hunting or fishing) require a minimum number of individuals involved (Ribeiro 1970; Pozzobon 1994),. Depending on the degree of resource stock reductions, habitat destruction may also remove activities related to subsistence even when there are enough individuals to perform them (Flowers 1994), pushing the cultural and numerical $\mathrm{E}$ to higher population sizes, increasing the odds of extinction during negative exogenous events (e.g., epidemics, drought) within populations with demographic evidence of the intra-cooperation process. These nations should invest in population size to counteract approaching the numerical and cultural E. Investing in population size to counter the negative effects of deforestation may also allow better territory defense and attract more media attention, which may translate into increased and improved governmental assistance and protection of nations' human rights, as occurred for the Karitiana, Krikatí, and Gavião Pykopjê (Ladeira, 1991; Ladeira and Azanha 1996, 2005a, 2005b).

Our results also captured the potential negative impact of deforestation on diet richness leading to compromised levels of nutrition, mentioned in nearly all the nations' chronicles (Junior 1985, 1989; Junior and Santos 1991; Fagundes et al. 2004; Orellana et al. 2006; S1 Table; S2, S4, S8 Text). This suggests that habitat destruction could exacerbate the decline of the per capita resource availability as population grows, as suggested by recent Xavante history and dynamics (S9 Text). Habitat destruction could result in a lower carrying capacity $(\mathrm{K})$, also increasing the odds of extinction during negative events. Deforestation increases dependence on family farm

Table 1 Parameter estimates for the model fitted to Mucaji Yanomami time series, with distinct time intervals between population size estimations. $R_{\max }, K$ and $E$ represent maximum per capita rate of change, carrying capacity and Allee population size, respectively

\begin{tabular}{lllll}
\hline Interval (years) & $R_{\max }$ & $K$ & $E$ & $\mathrm{R} 2$ \\
\hline 1 & $\mathbf{0 . 1 4}$ & $\mathbf{3 1 0 . 3 8}$ & $\mathbf{9 7 . 5 6}$ & $\mathbf{0 . 5 6}$ \\
3 & $\mathbf{0 . 2 7 7}$ & $\mathbf{3 0 8 . 2 9}$ & $\mathbf{9 9 . 7 3}$ & $\mathbf{0 . 6 7}$ \\
5 & $\mathbf{0 . 7 1 1}$ & $\mathbf{3 0 0 . 5 7}$ & $\mathbf{9 6 . 0 8}$ & $\mathbf{0 . 8 6}$ \\
\hline
\end{tabular}

$r^{2}$ is the coefficient of determination that measures the model fit for observed data. Significant results are in bold $(P<.05)$ 
Table 2 Results of the partial least squares regression analysis (PLS) of four Brazilian indigenous nations carried out with the estimated population per capita rate of change and four predictor variables (per capita natality, mortality, migration rates and population size)

\begin{tabular}{|c|c|c|c|c|c|c|c|c|}
\hline \multirow[t]{2}{*}{ Variables } & \multicolumn{2}{|c|}{ Kamaiurá } & \multicolumn{2}{|c|}{ Kawaiweté } & \multicolumn{2}{|l|}{ Ikpeng } & \multicolumn{2}{|l|}{ Kisêdjê } \\
\hline & W1 & W2 & W1 & W2 & W1 & W2 & W1 & W2 \\
\hline Natality & 0.610 & 0.124 & 0.732 & & 0.589 & 0.722 & 0.653 & 0.126 \\
\hline Mortality & -0.511 & 0.120 & -0.219 & 0.504 & 0.491 & & -0.497 & 0.332 \\
\hline Migration & -0.298 & -0.846 & 0.415 & 0.791 & 0.375 & -0.502 & 0.437 & 0.706 \\
\hline Population & 0.527 & -0.505 & 0.494 & -0.341 & -0.405 & 0.47 & 0.368 & -0.613 \\
\hline $\mathrm{R}^{2}$ & 44.225 & 23.807 & 54.256 & 39.766 & 64.628 & 22.461 & 55.297 & 31.065 \\
\hline
\end{tabular}

W1 and W2 are the loading weights of each variable in the first and second PLS regression components. $\mathrm{R}^{2}$ is the proportion of the variance in the response variable accounted by each component of the PLS regression. PLSR results and data inspections revels natality rates as the main driver of R changes, followed by population size, mortality levels and migration rates

production (Villas Bôas and Villas Bôas 1994; Flowers 1994; Junior et al. 2002; Instituto Socioambiental 2011; Nilsson and Fearnside, 2011; S9 Text). Within Brazilian indigenous communities, agriculture is mainly women's responsibility (Ribeiro 1970; da Silva, 1999), so that any increase in agricultural production could potentially produce a negative trade-off between family size and overall demographic fitness (Kaplan 1996; Hill and Kaplan 1999).

The intra-specific competition phenomenon implies that eventually all nations will suffer from the negative effects of population growth (Berryman 1999). The ultimate goal of indigenous nations and Brazilian governments should be to create conditions that enable nations to attain high and sustainable equilibrium population size (K). Indigenous nations with demographic evidence of intra-specific competition should invest in the creation of more villages to reduce the negative effects of local resource depletion. Diluting the population could allow higher and sustainable $\mathrm{K}$ while the Brazilian government continues to invest in the expansion of agricultural frontiers. The Brazilian government should invest in health care improvements, the creation of more ITs and villages to ease the negative effects of population growth.

Political and economic interests are the main impediments to the creation of new ITs and the extension of existing ones, as evidenced by the lack of impact of governmental and NGO projects on the demography of indigenous communities. International economic growth (e.g., China) increases demand for Brazilian natural commodities, pushing mono-agricultural frontiers closer to indigenous territories (IBGE 2014). As a significant proportion of Brazilian GDP, agribusiness has a strong political representation in the Brazilian congress, and its supporters are generally opposed to indigenous rights.

Table 3 Correlation matrix (Pearson) for the dataset gathered from Instituto Socioambiental website

Number ITs Territory Population Villages Extractive Land Gather Agriculture Hunt Gov- $\begin{aligned} & \text { Vegetation } \\ & \text { NGO }\end{aligned}$

\begin{tabular}{|c|c|c|c|c|c|c|c|c|c|c|c|}
\hline Number ITs & 1.00 & & & & & & & & & & \\
\hline Territory & 0.29 & 1.00 & & & & & & & & & \\
\hline Population & 0.90 & 0.13 & 1.00 & & & & & & & & \\
\hline Villages & 0.89 & -0.01 & 0.93 & 1.00 & & & & & & & \\
\hline Extractive & 0.54 & 0.27 & 0.58 & 0.55 & 1.00 & & & & & & \\
\hline Land & 0.69 & -0.03 & 0.71 & 0.77 & 0.72 & 1.00 & & & & & \\
\hline Gather & -0.27 & -0.27 & -0.08 & -0.06 & -0.29 & -0.27 & 1.00 & & & & \\
\hline Agriculture & -0.30 & -0.29 & -0.15 & -0.21 & -0.3 & -0.28 & 0.49 & 1.00 & & & \\
\hline Hunt & -0.30 & -0.10 & -0.25 & -0.20 & -0.07 & -0.12 & 0.58 & 0.5 & 1.00 & & \\
\hline Gov-NGO & -0.13 & -0.01 & -0.05 & -0.05 & -0.24 & -0.36 & 0.43 & 0.54 & 0.43 & 1.00 & \\
\hline Vegetation & 0.70 & 0.08 & 0.66 & 0.69 & 0.45 & 0.53 & -0.27 & -0.32 & -0.42 & -0.43 & 1.00 \\
\hline
\end{tabular}

Variables are: number of territories (N ITs), total territory size (Territory, $\mathrm{Km}^{2}$ ), initial population size (Population), number of villages (Villages), extractive pressure (Extractive), land pressure (Land), gathering diet items (Gather), agricultural items (Agriculture), hunting items (Hunt), government and non-government projects (Gov-NGO). Significant results in bold $(P<.05)$ 
Table 4 Partial least square regression analysis (PLS); results of the exploratory variables gathered from Instituto Socioambiental website on $\mathrm{dR}$ (the rate of change of per capita rate of change)

\begin{tabular}{llll}
\hline Variables & $\mathrm{W} 1$ & $\mathrm{~W} 2$ & $\mathrm{~W} 3$ \\
\hline Population & 0.633 & -0.316 & -0.643 \\
Territory & 0.176 & & 0.566 \\
Gather & 0.144 & 0.942 & -0.233 \\
Vegetation & 0.74 & & 0.461 \\
$R^{2} \%$ & 44.213 & 25.844 & 16.328 \\
\hline
\end{tabular}

Variables with low or no weights on PLS components were removed from the analysis and are not shown. W1, W2 and W3 represent the loading weights of each variable in the first, second and third PLS regression components. $R^{2} \%$ is the proportion of the variance in the response variable accounted for by each component of the PLS regression. All predictor variables were standardized

Consequently, the number of officially designated ITs has been declining drastically during the recent governments, while deforestation in favor of agriculture has been advancing (Instituo Socioambiental 2011). The platform of the recently elected president Jair Bolsonaro seems to represent a continuation of this trend, so it seems likely that indigenous communities will continue to suffer as a consequence of the belief of non-indigenous society that they represent a hindrance to economic growth (S10 Text).

Brazilian GDP estimates do not directly include the benefits of ecosystem services from natural reserves (IBGE 2014). Yet habitat degradation and the loss of natural services do impact actual GDP. For example, deforestation and urbanization in the Amazon region increased the frequency of malaria outbreaks and consequently governmental costs on health care (Amaral et al. 2001; Loioloa et al. 2002). Also, the Amazon forest influences rainfall regimes through humidity to the southeastern region, which has the most populous and important industrial centers in Brazil. Therefore, rain deficits, a product of deforestation, may impact energy costs and industrial productivity. In 2017, the government sanctioned a new law (No. 13.493/17) that incorporates costs of ecosystem services into GDP estimates, but how these estimates will be calculated and when the law will be implemented are still under debate. If and when it is implemented, the law may change the actual paradigm regarding hindrances to economic growth currently faced by ITs.

The United Nations Sustainable Development Goals (United Nations 2017) include the target of "Promot[ing] mechanisms for raising capacity for effective climate change-related planning and management in least developed countries and small island developing States, including focusing on women, youth and local and marginalized communities." Brazil has been and seems to be set to continue to follow policies contrary to such efforts to reduce the impacts of climate change as it continues to fuel the expansion of agricultural frontiers. The loss of nearly 800 distinct languages during the last centuries represents not only a demographic genocide, but also the loss of the indigenous human capital in the form of local environmental knowledge (LEK) acquired over millennia, including knowledge of food and medicinal plant species as well as the natural cycles of ecosystems and the services they provide. ${ }^{2}$ Also, LEK can be important to reforestation programs, as observed today in PIX where indigenous communities collect the seeds for a project aiming to rehabilitate the degraded headwaters of Xingu's hydrographic basin. It is also notable that smallscale agriculture as practiced in indigenous communities allows for greater diversity than commercial monocultures and is less affected by pests, reducing the demand for and use of pesticides (Instituto Socioambiental 2011).

The demographic recovery of indigenous populations in Brazil allowed better territory protection and surveillance as well as intra- and inter-nation social mobilization to pressure the government to guarantee land rights that potentially impact the demographic recovery pattern. For example, the population growth of the Karitiana, Krikatí, and Gavião Pykopjê nations allowed better internal organization and also attracted media attention that ultimately led to guaranteed land rights, changing the $\mathrm{R}$ decline to increase. The inter-nations' mobilizations together with the efforts of pro-indigenous NGOs and universities act to counteract the agribusiness agenda of the government (see https://pib.socioambiental.org/pt/Lista_de organiza\%C3\%A7\%C3\%B5es_de_apoio_aos_povos_ind $\%$ C3\%ADgenas).

Education may be the best way to construct a future social awareness in Brazilian society as well as the international community of the current situation and potential contributions of indigenous nations, and most particularly to counteract the secular paradigm that indigenous nations are a threat to economic growth. The new national curricular base in Brazil (approved by the congress and the senate in 2017) clearly includes under History the valorization of afro- and indigenous cultures (Law n ${ }^{\circ} 10.639 / 200349$ and Law ${ }^{\circ} 11.645 / 200850$ ). If successfully implemented, these new guidelines might change social and political awareness of indigenous rights established in the 1988 Constitution (S10 Text).

\section{Conclusion}

Most of the population predictions of human dynamics are deterministic or stochastic projections of current

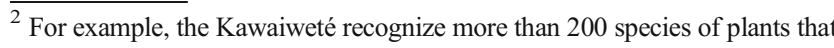
can be cultivated for agricultural purposes (Instituto Socioambiental 2011).
} 


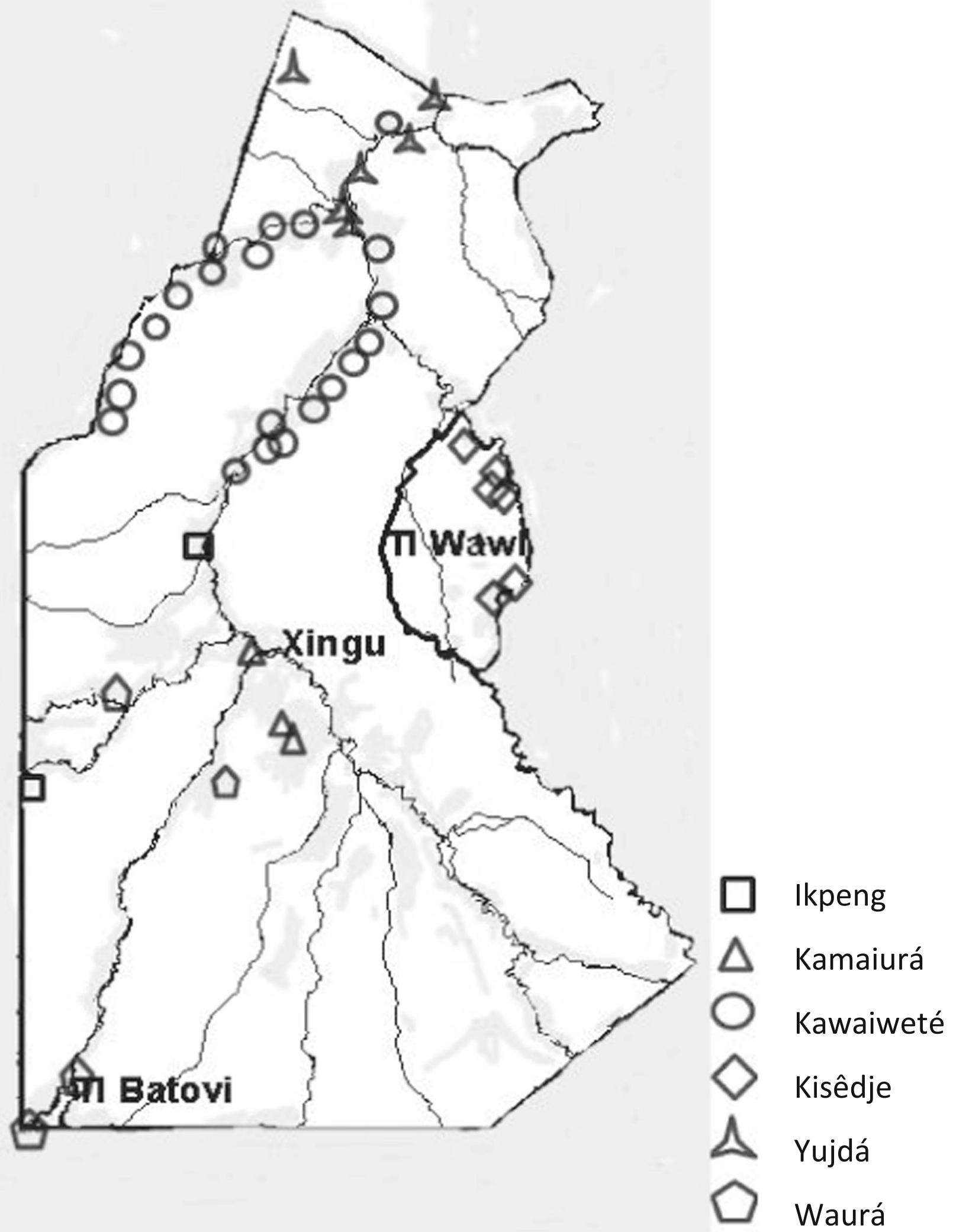

Fig. 9 The distribution of villages (triangles) per nation and indigenous posts (squares) inside PIX. The Kaiabis are the Kawaiwete. Kawaiwetes and Kisêdjês have more villages and most of them are located near agriculture frontiers. Source: Instituto Socioambiental, 2011 
trends based either on exponential or faster than exponential growth models (Galor and Weil 2000; Lutz et al. 2006). These approaches are problematic because they are not based on general principles of population dynamics. Consequently, most of the human population dynamics forecasts derive from inappropriate models because they do not take into account the effects of limiting factors and potential feedback loops (Royama 1992; Berryman 1999). By exploring the dynamics and the recent history of indigenous nations with the proper ecological principles we were able to correlate exogenous variables and processes (such as the introduction of health care and advances of agriculture frontiers) with population size. The ecological principles helped to disentangle the complex universe of variables in which indigenous populations live. The framework encourages hypothesizing and testing processes that could affect population dynamics and would be readily applicable across a range of human societies.

Acknowledgements We would like to thank to all researchers and members of governmental and non-governmental agencies who have dedicated their lives to defend the rights of the indigenous nations to persist.

Funding FAMK and FAC was supported by $\mathrm{PhD}$ scholarships from CONICYT and Pontificia Catholic University of Chile. ML was supported by Fondo Basal-CONICYT grant FB- 0002 and Proyecto Fondecyt Regular 1141164.

\section{Compliance with Ethical Standards}

Conflict of Interest The authors declare that they have no conflict of interest.

Open Access This article is distributed under the terms of the Creative Commons Attribution 4.0 International License (http:// creativecommons.org/licenses/by/4.0/), which permits unrestricted use, distribution, and reproduction in any medium, provided you give appropriate credit to the original author(s) and the source, provide a link to the Creative Commons license, and indicate if changes were made.

\section{References}

Abrera, B. G., Franky, C. E. C., and Mahecha, R. D. (1995). Demografia y movilidad socio-espacial de los Nukak, Fundación Gaia, Bogotá.

Albert B. (1999) Instituto Socioambiental. Povos Indigenas do Brasil. https://pib.socioambiental.org/pt/povo/yanomami (Accessed 2 January, 2018).

Allee, C. W. (1932). Animal aggregations: A study in general sociology, University of Chicago Press, Chicago.

Almeida, R. R. M. (2004). Traduções do Fundamentalismo Evangélico. In R. M. Wright (Ed.), Transformando os Deuses: Igrejas evangélicas, pentecostais e neopentecostais entre os povos indígenas no Brasil (pp. 33-53), Campinas: Editora da UNICAMP).

Amaral, S., Câmara, G., Monteiro, A. M.V. (2001). Análise Espacial do Processo de Urbanização da Amazônia. INPE.
Andrade, L. (1992). O corpo e o cosmos: relações de gênero e o sobrenatural entre os Asurini do Tocantins. [dissertation/master's thesis]. [São Paulo]: USP.

Andrade L. (1999) Instituto Socioambiental. Povos Indígenas do Brasil. https://pib.socioambiental.org/pt/povo/asurini-do-tocantins (accessed 2 January, 2018).

Arnaud, E. (1984). Os índios Palikúr do rio Urucauá: tradição tribal e protestantismo, MPEG, Belém.

Arnaud, E. (1989a). O índio e a expansão nacional. Boletim do MPEG Cejup, 315-64.

Arnaud, E. (1989b). Os índios da região do Uaçá (Oiapoque) e a proteção oficial brasileira. In Arnaud, E. (ed.), O índio e a expansão nacional, Cejup, Belém, pp. 87-128.

Arnaud, E. (1993). As questões ambientais na fronteira Oiapoque/Guiana Francesa: os Galibi, Karipuna e Palikur. In Santos, A. C. M. (ed.), Sociedades indígenas e transformações ambientais, UFPA-Numa, Belém, pp. 47-60.

Arruda, R. S. V. (1987). Relatório de avaliação da Área Indígena Rikbaktsa-Japuíra e da área Indígena do Escondido. S.I: Fipe/Minter/Sudeco.

Arruda, R. S. V. (1992). Os Rikbaktsa: mudança e tradição. [dissertation/ Phd]. [São Paulo]: PUC.

Arruda, R. S. V. (1996). Os direitos dos Rikbaktsa: interesses impedem demarcação da Área Indígena do Escondido. In Ricardo, C. A. (ed.), Povos Indiígenas no Brasil: 1991/1995, Instituto Socioambiental, São Paulo, pp. 579-582.

Artionka C. (2012). Instituto Socioambiental. Povos Indígenas do Brasil. https://pib.socioambiental.org/pt/povo/palikur (accessed 2 January, 2018).

Balée, W. (1992). Peoples of the Fallow: A Historical Ecology of Foraging in Lowland South America. In Redford, K., and Padoch, C. K. (eds.), Conservation of Neotropical Forests: Working from Traditional Resource Use, Columbia Universty Press, New York, pp. 35-57.

Barbosa, R. I., Pinto, F. D. S., and De Souza, C. C. (2008). Desmatamento em Roraima: Dados históricos e distribuição espaço-temporal. Relatório técnico Ministério da Ciência e Tecnologia, IMPA, Roraima.

Barros, E. P. (1989). Os Bakairi, Fundação Pró-Memória, BrasíliaR.

Barros E P. (1999). Instituto Socioambiental. Povos Indígenas do Brasil. https://pib.socioambiental.org/pt/povo/bakairi (accessed 2 January, 2018).

Barros, E. P. et al. (1994). Laudo histórico-antropoógico: Ação de desapropriação indireta - processo n. 17624/86-V. Direitos indígenas e antropologia: laudos periciais em Mato Grosso MALDI (pp. 96-174). Cuiabá: UFMT.

Baruzzi, R. G. (2005). Do Araguaia ao Xingu. In Parque Indígena do Xingu. Saúde, Cultura e História. São Paulo, BR: Terra Virgem.

Bates, D. M., and Watts, D. G. (1988). Nonlinear Regression Analysis and its Applications, Wiley, New York.

Belovsky, E. G. (1988). An optimal foraging-based model of huntergatherer population dynamics. Journal of Anthropological Archaeology 7(4): 329-312.

Berryman, A. A. (1999). Principles of population dynamics and their application, Stanley Hornes, USA.

Berryman, A. A., and Turchin, P. (2001). Identifying the DensityDependent Structure Underlying Ecological Time Series. Oikos 92(2): 265-270.

Boserup, E. (1965). The conditions of agricultural growth: The economics of agrarian change under population pressure, AldineTransaction, USA.

Boserup, E. (1981). Population and technological change: A study of long-term trends (p. xi), University of Chicago Press, USA.

Brando, P. M., Coe, M. T., DeFries, R. S., and Azevedo, A. (2013). Ecology, economy, and management of an agroindustrial frontier landscape in the southeast Amazon. Philosophical Transactions of 
the Royal Society B: Biological Sciences. https://doi.org/10.1098/ rstb.2012.0152.

Carrascal, L. M., et al (2009). Partial least squares regression as an alternative to current regression methods used in ecology. Oikos 118(5): 681-690.

Chu, C. Y. C., and Tai, C. (2001). Ecosystem resilience, specialized adaptation and population decline: A modern malthusian theory. Journal Population Economic 14(1): 7-19.

Coelho, E. M. B. (1998). A política indigenista oficial na dinâmica da disputa pela terra: o caso da demarcação da terra Krikati. In Barreira, S. V. (ed.), Cultura e política: tecidos do cotidiano brasileiro, UFCE, Fortaleza, pp. 51-75.

Coutinho, J. W. (1989). Relatório de identificação e delimitação da Terra Indígena Vale do Javari: GT Portarias n. 174/95 e 158/96. Brasília: FUNAI.

Crocker, W. H. (2002). Instituto Socioambiental. Povos Indígenas do Brasil. http://pib.socioambiental.org/pt/povo/canela-ramkokamekra (accessed 2 January, 2018).

da Silva, G. M. (1999). Agricultura Kaiabi e Yudja na paisagem norte do Parque Indígena do Xingu, Instituto Socioambiental, São Paulo.

De Castro, V. E. (1988). Os Araweté. In Santos, L. A., and Andrade, L. M. M. (eds.), Hidrelétricas do Xingu e os povos indígenas, CPI-SP, São Paulo, pp. 179-184.

De Castro, E. V. (2003). Instituto Socioambiental. Povos Indígenas do Brasil. https://pib.socioambiental.org/pt/povo/arawete (accessed 2 January, 2018).

De Oliveira, L. A. P., and De Oliveira, A. T. R. (2011). Reflexões sobre os Deslocamentos Populacionais no Brasil. IBGE: 1-103.

De Queiroz, R. C. (2000). Instituto Socioambiental. Povos Indígenas do Brasil. https://pib.socioambiental.org/pt/povo/hixkaryana (accessed 2 January, 2018).

de Toral, A. A. (1981). Os Javaé e a defesa de sua terra, Global, São Paulo.

Demolin, D., and Storto, L. (1980). Some Aspects of Karitiana Food Economy. Arquivos de Anatomia e Antropologia 4: 225-241.

Early, J. D., and Peters, J. P. (1990). The population dynamics of the Mucajai Yanomama, Academic Press, San Diego.

Elton, C. S. (1958). Ecology of invasions by animals and plants, Chapman and Hall, London.

Fagundes, U., Kopelman, B., Oliva, C. A. G., Baruzzi, R. G., and Fagundes-Neto, U. (2004). Avaliação do estado nutricional e da composição corporal das crianças índias do Alto Xingu e da etnia Ikpeng. Jornal de Pediatria 80(6): 483-489.

Fearnside, P. M. (2005). Desmatamento na Amazônia brasileira: história, índices e conseqüências. Megadiversidade 1(4): 113-123.

Ferreira, M. K. L. (1994). Histórias do Xingu: coletânea de depoimentos dos índios Suyá, Kayabi, Juruna, Trumai, Txucarramãe e Txicão, USP, São Paulo, BR.

Filho, A. C., and de Souza, O. B. (2009). Atlas de Pressões e Ameaças às Terras Indígenas na Amazônia Brasileira, Instituto Socioambiental, São Paulo.

Flowers, N. (1994). Demographic crisis and recovery: A case study of the Xavante of Pimentel Barbosa. In Adams, K. P., and Junior, D. P. (eds.), The demography os small-scale societies: Case studies from lowland South America, Bernnington College, Bernnington, pp. 18-36.

Fortune, D. L., and Fortune, G. (1948). The Carajá. Handbook of South American Indians 3: 179-191.

Frikel, P. (1972). Migração, guerra e sobrevivência Suia. Revista de Antropologia. USP 20: 105-136.

Gallois, D. T. 1997. Instituto Socioambiental. Povos Indígenas do Brasil. https://pib.socioambiental.org/pt/povo/wajapi (accessed 2 January, 2018).

Galor, O., and Weil, D. N. (2000). Population, technology, and growth: From Malthusian stagnation to the demographic transition and beyond. The American Economic Review 90(4): 806-828.
Galvão, E. (1979). Apontamentos sobre os índios Kamaiurá. Estudos Brasileiros 29: 17-38.

Garfield, S. (2001). Indigenous struggle at the heart of Brazil: State policy, frontier expansion, and the Xavante indians, 1937-1988, Duke University Press, Durhan.

Ginzburg, L. R. (1986). The theory of population dynamics: Back to first principles. Journal of Theoretical Biology 122(4): 385-399.

Gomes, M. P. (2000). The Indians and Brazil. Gainesville, University Press of Florida, Florida.

Gonçalvez, J. R. S. (1981). A luta pela identidade social: o caso da relações entre índios e brancos no Brasil Central. [dissertation/master's thesis]. [Rio de Janeiro]: UFRJ-Museu Nacional.

Grahan, L. (2008). Instituto Socioambiental. Povos Indígenas do Brasil. http://pib.socioambiental.org/pt/povo/xavante (accessed 2 January, 2018).

Gregory, S. D., Bradshaw, J. A., Brook, B. W., and Courchamp, F. (2010). Limited evidence for the demographic Allee effect from numerous species across taxa. Ecology 91(7): 2151-2161.

Grenand, P. (1992). The use and cultural significance of the secondary forest among the Wayapi Indians, in sustainable harvest and marketing of rain forest products. In Plotkin, M. J., and Famolare, L. (eds.), Conservation International, Island Press, Washington, pp. 27-40.

Guggelmin, S. A. (2001). Antropometria nutricional e ecologia humana dos Xavante de Sangradouro - Volta Grande, Mato Grosso. [dissertation/PhD]. [Rio de Janeiro]: FIOCRUZ.

Hamilton, M. J., Burger, O., DeLong, J. P., Walker, R. S., Moses, M. E., and Brown, J. H. (2009). Population stability, cooperation, and the invisibility of the human species. Proceedings of the National Academy of Sciences of the United States of America 106(30): 12255-12260.

Hill, K., and Hurtado, M. (1996). Ache life history: The ecology and demography of a foraging people, Aldine de Gruyter, New York.

Hill, K., and Kaplan, H. (1999). Life history traits in humans: Theory and empirical studies. Annual Review of Anthropology 28(1): 397-430.

Hopfenberg, R. (2003). Human carrying capacity is determined by food availability. Population and Environment 25(2): 109-117.

Hotz, V. J., and Miller, R. A. (1988). An empirical analysis of life cycle fertility and female labor supply. Econometrica 56(1): 91-118.

Instituto Brasileiro de Geografia e Estatística (2010). Censo demográfico 2010: Características Gerais dos Indígenas - Resultados do Universo, IBGE, Brazil.

Instituto Brasileiro de Geografia e Estatística (2014). Indicadores IBGE. Indicadores de volume e valore correntes. IBGE Contas Nacionais Trimestrais 4: 1-40.

Instituto Socioambiental (2011). Almanaque Sócio Ambiental Parque Indígena do Xingu 50 anos, Instituto Socioambiental, São Paulo, BR.

Junior, C. E. A. C. (1985). Estudos de ecologia humana entre os Suruí do Parque Indígena Aripuanã, Rondônia: Aspectos alimentares. Boletim do MPEG, Série Antropologia 2(2): 57-87.

Junior, C. E. A. C. (1989). From shifting cultivation to coffee farming: the impact of change on the health and ecology of the Suruí indians in the Brazilian Amazon. [dissertation/ $\mathrm{PhD}$ thesis]. [Indiana: Indiana University].

Junior, C. E. A. C., and Santos, R. V. (1991). Avaliação do estado nutricional num contexto de mudança sócio-econômica: o grupo indígena Suruí do Estado de Rondônia, Brasil. Cadernos de Saúde Pública, Rio de Janeiro Fiocruz 7(4): 538-562.

Junior, C. E. A. C., Flowers, N. M., Salzano, F. M., and Santos, R. V. (2002). The Xavante in transition: Health, ecology and bioanthropology in Central Brazil, University of Michigan Press, Michigan.

Junqueira, C. (1967). Os Kamaiurá e o Parque Nacional do Xingu. [dissertation/PhD]. [Campinas]: Unicamp. 
Junqueira, C. (2002). Sexo e desigualdade entre os Kamaiurá e os Cinta Larga, CAPES, São Paulo.

Junqueira C. (2003). Instituto Socioambiental. Povos Indígenas do Brasil. https://pib.socioambiental.org/pt/povo/kamaiura (accessed 2 January, 2018).

Junqueira, C., Lima, A., and Lafer, B. (1982). Terra e conflito no Parque do Aripuanã: o caso Suruí. In Santos, S. C. (ed.), O índio perante o direito, UFSC, Florianópolis, pp. 111-116.

Kaplan, H. (1996). A theory of fertility and parental investment in traditional and modern human societes. American Journal of Physical Anthropology 101(39): 91-135.

Ladeira, M. E. (1991). Krikati: um longo processo para o reconhecimento de suas terras. In Ricardo, C. A. (ed.), Povos Indígenas no Brasil: 1987/88/89/90, Cedi, São Paulo, pp. 491-492.

Ladeira, M. E., and Azanha, G. (1996). Os "Timbira atuais" e a disputa territorial. In Ricardo, C. A. (ed.), Povos Indígenas no Brasil: 1991/1995, Instituto Socioambiental, São Paulo, pp. 637-641.

Ladeira, M. E., and Azanha, G. (2003). Instituto Socioambiental. Povos Indigenas do Brasil. https://pib.socioambiental.org/pt/ povo/apinaye (accessed 2 January, 2018).

, M. E., and Azanha, G. (2005a). M., E., L. Instituto Socioambiental. Povos Indígenas do Brasil. https://pib.socioambiental.org/pt/povo/gaviaopykopje (accessed 2 January, 2018).

Ladeira, M. E., and Azanha, G. (2005b). Instituto Socioambiental. Povos Indigenas do Brasil. http://pib.socioambiental.org/pt/povo/krikat (accessed 2 January, 2018).

Lanna, A. D. (1966). Aspectos econômicos da organização social dos Kĩsêdjê. [dissertation/master's thesis]. [São Paulo]: USP.

Leitão, A. V. N. A. (1995). A defesa dos direitos indígenas no judiciário: ações propostas pelo Núcleo de Direitos Indígenas, Instituto Socioambiental, São Paulo.

Lemos, A. L. F., and Silva, J. D. A. (2011). Desmatamento na Amazônia legal: Evolução, causas, monitoramento e possibilidades de mitigação através do fundo Amazônia. Floresta e Ambiente 18(1): 98-108.

Lima, T. S. (2001). Instituto Socioambiental. Povos Indigenas do Brasil. https://pib.socioambiental.org/pt/povo/yudja (accessed 2 January, 2018).

Lima, M. (2009). A link between the North Atlantic oscillation and measles dynamics during the vaccination period in England and Wales. Ecology Letters 12(4): 302-314.

Lima, M. (2014). Climate change and the population collapse during the "great famine" in pre-industrial Europe. Ecology and Evolution 4(3): 284-291.

Lima, M., and Berryman, A. A. (2011). Positive and negative feedbacks in human population dynamics: Future equilibrium or collapse? Oikos 120(9): 1301-1310.

Lima, M., Christie, D. A., Santoro, M. C., and Latorre, C. (2016). Coupled socio-environmental changes triggered indigenous Aymara depopulation of the semiarid Andes of Tarapacá-Chile during the late 19th-20 ${ }^{\text {th }}$ centuries. PLoS ONE 8: e0160580. https://doi. org/10.1371/journal.pone.0160580.

Loiola, C. C. P., da Silva, C. J. M., and Tauil, P. L. (2002). Controle da malária no Brasil: 1965 a 2001. Pan American Journal of Public Health 11(4).

Longarezi, A. M. (1993). Os Kayabi. Terra Indígena, Araraquara. Centro de Estudos Indígenas 10: 40-50.

Lotka, A. J. (1925). Elements of physical biology. Baltimore: Williams and Wilkins. Reprinted as elements of mathematical biology, Dover Publications, New York.

Luděk, B., Angulo, E., and Courchamp, F. (2006). Multiple allee effects and population management. TRENDS in Ecology and Evolution 22(4): 185-191.

Lutz, W., Teta, M. R., and Penn, D. J. (2006). Population Density as a Key Factor in Declining Human Fertility. Population and Environment 28(2): 69-81.
MacArthur, R. H. (1955). Fluctuation of Animal Populations and a Measure of Community Stability. Ecology 36(3): 533-536.

Machado, M., Pagliaro, H., and Baruzzi, R. G. (2009). Perfil demográfico dos Hupd'ah, povo Maku da região do Alto Rio Negro, Amazonas (2000-2003). R. Bras. Est. Pop. 26(1): 37-50.

Maia, S. F., De Albuquerque, R. O., Pagliaro, H., Rodrigues, D., and Baruzzi, R. G. (2004). A recuperação populacional dos Txicão (Ikpeng), parque indígena do Xingu, Mato Grosso, Brasil. Anais do XIV Encontro Nacional de Estudos Populacionais, Caxambu, Caxambu.

Malthus, R. T. (1798). An essay on the principle of population as its affects the future improvement of society; with remarks on the speculations of Mr Godwin, M. Condorcet, and other writers, J. Johnson, London.

McSweeney, K., and Shahna, A. A. (2005). Demographic turnaround: The rapid growth of indigenous populations in lowland Latin America. Latin American Research Review 40(1): 3-29.

Medeiros, L. (2000). Population dynamics of the Waiãpi of Brazil: Demographic insights on the changing reproductive behavior of an indigenous culture. [dissertation/Bachalor's thesis]. [Chicago]: University of Chicago.

Melatti, J. C. (1993). Índios do Brasil, Hucitec, São Paulo.

Melatti, J. C. (1994). Craho. In Wilbert (ed.), Encyclopedia of world cultures, G. K. and CO, Boston, pp. 135-139.

Melatti J C. (1998). Instituto Socioambiental. Povos Indígenas do Brasil. https://pib.socioambiental.org/pt/povo/marubo (accessed 2 January, 2018).

Melatti J C. (1999). Instituto Socioambiental. Povos Indigenas do Brasil. https://pib.socioambiental.org/pt/povo/kraho (accessed 2 January, 2018).

Menget P. (2003). Instituto Socioambiental. Povos Indígenas do Brasil. https://pib.socioambiental.org/pt/povo/ikpeng (accessed 2 January, 2018).

Mevik, B. H., and Wehrens, R. (2007). The pls package: Principal components and partial least squares regression in R. Journal of Statistical Software 18(2): 1-24.

Mindlin, B. (1985). Os Paiter: os Suruí de Rondônia, Vozes, Petrópolis.

Mindlin, B. (1991). Os Paiter: vinte anos depois. In Ricardo, C. A. (ed.), Povos Indígenas no Brasil : 1987/88/89/90, Cedi, São Paulo, p. 437.

Mindlin B. (2003). Instituto Socioambiental. Povos Indigenas do Brasil. https://pib.socioambiental.org/pt/povo/surui-paiter (accessed 2 January, 2018).

Montagner, D., and Melatti, J. C. (1975). Relatórios sobre os índios Marúbo, UnB, Brasilia.

Monteiro, M. E. B. (1984). Relatório sobre os índios Karitiana - Estado de Rondônia, SEDOC-FUNAI, Rio de Janeiro.

Moser, L. (1997). Os Karitiana no processo de desenvolvimento de Rondônia nas décadas de 1950 a 1990. [dissertation/master's thesis]. [Recife]: UFPE.

Naes, T., and Martens, H. (1985). Comparison of Prediction Methods for Multicollinear Data. Communications in Statistics, Simulation and Computation 14(3): 545-576.

Newton, D. (1971). Social and historical dimensions of Timbira material culture, Harvard University, Cambridge.

Nilsson, M. S. T., and Fearnside, P. M. (2011). Yanomami mobility and its effects on the forest landscape. Human Ecology 39(3): 235-256.

Ninuendajú, C. (1948a). The Cayabi, Tapanyuna, and Apiaca. In Steward, J. H. (ed.), Handbook of south American Indians, Smithsonian Institution, Washington, pp. 307-320.

Ninuendajú, C. (1948b). Tribes of the lower and middle Xingu river. In Steward, J. (ed.), Handbook of South American Indians, Smithsonian Institution, Washington, pp. 213-243.

Ninuendajú, C. (1976). A habitação dos Timbíra. In Schaden, E. (ed.), Leituras de etnologia brasileira, Companhia Editôra Nacional, São Paulo, pp. 44-62.

Ninuendajú, C. (1983). Os Apinayé, MPEG, Belém. 
Oakdale, S. R. (1996). The power of experience: Agency and identity in Kayabi healing and political process in the Xingu Indigenous Park. [dissertation/PhD]. [Chicago]: University of Chicago.

Oberg, K. (1948). The Bacairi of Northern of Mato Grosso. Southwesten Journal of Anthropology 4(3): 305-319.

Oberg, K. (1953). The Camayurá. In Indian tribes of northern Mato Grosso, Brazil, Smithsonian Institution, Washington, pp. 1-68.

Odum, E. P. (1953). Fundamentals of ecology, Saunders, Philadelphia.

Oliveira, A. E. (1969). Os índios Juruna do Alto Xingu. [dissertation/ $\mathrm{PhD}$ ]. [Rio Claro]: Fac. de Filosofia de Rio Claro.

Orellana, J. Y. D., Junior, C. E. A. C., Lourenço, A. E. P., Santos, R., and V. (2006). Nutritional status and anemia in Suruí indian children, Brazilian amazon. Jornal de Pediatria 82(5): $383-388$.

Pagliaro, H. (2002). A revolução demográfica dos Povos Indígenas: a experiência dos Kaiabi do Parque Indígena do Xingu, Mato Grosso (1970-1999). [dissertation/PhD]. [São Paulo]: USP.

Pagliaro, H., and Junqueira, C. (2007). Recuperação demográfica e fecundidade dos Kamaiurá, povo Tupi do Parque Indígena do Xingu, Brasil Central, 1970-2003. Saúde e Sociedade 16(2): 37-47.

Pagliaro, H., Azevedo, M. M., and Santos, R. V. (2005). Demografia dos povos indígenas no Brasil, FIOCRUZ, Rio de Janeiro.

Pagliaro, H., Junqueira, C., Mendaña, L. G. S., Mendonça, S. B., and Baruzzi, R. G. (2008). Dinâmica demográfica dos Kamaiurá, povo Tupi do Parque Indígena do Xingu, Mato Grosso, Brasil, 19701999. Revista Brasileira de Estudos de População 25(2): 377-388.

Pagliaro, H., Mendonça, S., and Baruzzi, R. (2009). Fecundidade e saúde reprodutiva das mulheres Suyá (Kisêdjê): aspectos demográficos e culturais. Caderno CRH 22(57): 479-491.

Paula, L. R. (2005). Terras Indígenas sofrem pressão do agronegócio. In Ricardo, C. A., and Ricardo, F. (eds.), Povos Indígenas no Brasil, Instituto Socioambiental, São Paulo, pp. 737-739.

Pennington, R., and Harpending, H. (1988). Fitness and Fertility Among Kalahari! Kung. American Journal of Physical Anthropology 77(3): 303-319.

Picchi, D. S. (2000). The Bakairi Indians of Brazil; politics, ecology and change, Waveland Press, Indiana.

Picchi D S. (2003). Instituto Socioambiental. Povos Indigenas do Brasil. https://pib.socioambiental.org/pt/povo/nahukua (accessed 2 January, 2018).

Pozzobon, J. (1994). O mínimo demográfico de um sistema de metades exogâmicas. Revista Brasileira de Estudos Populacionais 11(2): $139-154$.

Reid, H. (1979). Some aspects of movement, growth and change among Hupdu Maku Indians in Brazil [dissertation/PhD], [Cambridge (IL)]: University of Cambridge.

Ribeiro, D. (1956). Convívio e contaminação. Efeitos dissociativos da depopulação provocada por epidemias em grupos indígenas. Sociologia 18: 3-50.

Ribeiro, D. (1970). Os índios e a civilização. A integração dos indígenas no Brasil moderno, Rio de Janeiro, Civilização Brasileira.

Ricardo, C. A. (2000). Povos Indígenas do Brasil: 1996-2000, Instituto Socioambiental, São Paulo.

Rodrigues, A. J. (1994). Ecology of the Kayabi indians of Xingu, Brazil: Soil and agroforestry management. [dissertation/PhD]. [Cambridge]: University of Cambridge.
Rodrigues P M. (2010). Instituto Socioambiental. Povos Indigenas do Brasil. https://pib.socioambiental.org/pt/povo/javae (accessed 2 January, 2018).

Royama, T. (1992). Analytical population dynamics, Chapman and Hall, London.

R Development Core Team (2016) R: A Language and Environment for Statistical Computing. R Foundation for Statistical Computing, Vienna.

Salomão, R. D. P., et al (2007). The forests of Belo Monte on the great curve of the Xingu River, Eastern Amazon. Bolletim do Museu Paraense Emílio Goeldi Ciências Humanas 2(3): 57153.

Schultz, H. (1962). Informações etnográficas sobre os índios Kĩsêdjê, 1960. Rev. do Museu Paulista, São Paulo 13: 315-332.

Seeger, A. (1980). A identidade étnica como processo: os índios Kĩsêdjê e as sociedades do Alto Xingu. Anuário Antropológico, Rio de Janeiro: Tempo Brasileiro 78: 56-75.

Seeger A. (2003). Instituto Socioambiental. Povos Indigenas do Brasil. http:// pib.socioambiental.org/pt/povo/kisedje (accessed 2 January, 2018).

Senra K. (1999). Instituto Socioambiental. Povos Indigenas do Brasil. https://pib.socioambiental.org/pt/povo/kawaiwete (accessed 2 January, 2018).

Simões, M. E. (1963). Os "Txikão" e outras tribos marginais do alto Xingu. Rev. do Museu Paulista, São Paulo 14: 76-105.

Smith, E. A., and Winterhalder, B. (2003). Human behavioral ecology. Encyclopedia of Cognitive Science 2: 377-385.

Storto L and Ferreira F. (2005). Instituto Socioambiental. Povos Indigenas do Brasil. http://pib.socioambiental.org/pt/povo/karitiana (accessed 2 January, 2018).

Tavares, S. C. (1994). A reclusão pubertaria no Kamayurá de Ipawu: um enfoque biocultural. [dissertation/master's thesis]. [Campinas]: UNICAMP.

Tobias, R. D. (2003). An introduction to partial least squares regression. http://www.ats.ucla.edu/stat/sas/library/pls. Accessed 2013.

Turchin, P. (2001). Does Population Ecology Have General Laws? Oikos 94(1): 17-26.

UN. (2017). The Sustainable Development Goals Report, United Nations, Geneva.

Verhulst, P. F. (1838). Notice sur la loi que la population suit dans son accrossement. Corr. Math. Phys 10: 113-121.

Viertler, R. B. (1969). Os Kamayurá do Alto Xingu: análise do processo de integração de uma tribo numa área de aculturação intertribal. [dissertation/master's thesis]. [São Paulo]: IEB.

Villas Bôas, A. (1996). Kĩsêdjê lutam pela preservação de seu território. In Ricardo, C. A. (ed.), Povos Indígenas no Brasil: 1991/1995, Instituto Socioambiental, São Paulo, pp. 618-621.

Villas Bôas, C., and Villas Bôas, O. (1994). A marcha para o oeste: a epopéia da expedição Roncador-Xingu, Globo, São Paulo.

Wagley, C. (1951). Cultural influences on population: A comparison of two Tupi tribes, Museu Paulista, São Paulo.

Walker, R., et al (2006). Growth Rates and Life Histories in Twenty-Two Small-Scale Societies. American Journal of Human Biology 18(3): 295-311.

Wurker, E. (1999). A saúde da nossa comunidade: povos Matipu, Kalapalo e Nahukua, Instituto Socioambiental, São Paulo.

Publisher's Note Springer Nature remains neutral with regard to jurisdictional claims in published maps and institutional affiliations. 